\title{
Antimicrobial activities of some narrow endemic gypsopyhte
}

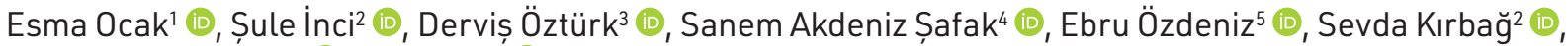 \\ Ahmet Harun Evren² (D), Latif Kurt ${ }^{5}$ (D)
}

1'Osmangazi University, Faculty of Science and Literacy, Department of Chemistry, Eskișehir, Turkey

${ }^{2}$ Fırat University, Faculty of Science, Department of Biology, Elazığ, Turkey

${ }^{3}$ Osmangazi University, Mahmudiye Horse Breeding Vocational School, Eskișehir, Turkey

${ }^{4}$ Aksaray University, Faculty of Science and Liretacy, Department of Biology, Aksaray, Turkey

${ }^{5}$ Ankara University, Faculty of Science, Department of Biology, Ankara, Turkey

ORCID IDs of the authors: E.0.0000-0002-9085-4151; S.I. 0000-0002-4022-5269; D.0̈. 0000-0001-7189-7407;

S.A.Ș. 0000-0002-7660-9109; E.Ö. 0000-0003-4082-3071; S.K.0000-0002-4337-8236; A.H.E.0000-0003-1598-3065;

L.K. 0000-0003-1598-3065

Cite this article as: Ocak, E., Inci, S., Ozturk, D., Akdeniz Safak, S., Ozdeniz, E., Kirbag, S. ... Kurt, L. (2021). Antimicrobial activities of some narrow endemic gypsopyhte. Istanbul Journal of Pharmacy, 51(1), 118-122.

\begin{abstract}
Background and Aims: In this study, antimicrobial activities of extracts obtained from narrowly dispersed local endemic gypsophytes grown in extreme habitats were investigated for the first time. The aim of this study was to analyzed antimicrobial effects of narrow endemic plants that are Thymus ekimii Yildirimli, Verbascum gypsicola Vural \& Aydogdu, Glaucium secmenii Yildirimli and Psephellus erzincani Wagenitz \& Kandemir.

Methods: Antimicrobial activity of T. ekimii, V. gypsicola, G. secmenii and P. erzincani were determined according to the disk diffusion method. The microorganisms used for the present investigation; gram positive bacteria, gram negative bacteria and yeasts (Bacillus megaterium DSM32, Escherichia coli ATCC25922, Candida albicans FMC17).

Results: According to the results obtained, P. erzincani showed the best antimicrobial activity against $B$. megaterium DSM32 $(23 \mathrm{~mm})$, E. coli ATCC25922 $(15 \mathrm{~mm})$ and C. albicans FMC17 $(23 \mathrm{~mm})$, respectively.

Conclusion: This study showed that extracts of these endemic plants have the potential for use as antimicrobial agents, especially $P$. erzincani.

Keywords: Thymus ekimii, Verbascum gypsicola, Glaucium secmenii, Psephellus erzincani, antimicrobial activity, gypsopyhte
\end{abstract}

\section{INTRODUCTION}

The increasing resistance of bacteria to clinical antibiotics necessitates the development of new agents in the treatment of diseases. Therefore, antibacterial and antifungal effects of herbal preparations are very important due to the high incidence of antibiotic resistance in treatment (Mummed, Abraha, Feyera, Nigusse, \& Assefa, 2018). Some studies showed that plants can be successful in overcoming antibiotic resistance with combinatorial approaches (Van Vuuren \& Viljoen, 2011; Hutchings \& Cock, 2018; Blonk \& Cock, 2019). Today, 80\% of the active substances used in the treatment of infectious diseases are thought to be vegetable-oriented (Özdek, Seçkin, \& Çibuk, 2020). Therefore, the use of plant extracts as an antioxidant and antimicrobial agent has been expanded in recent years.

Among the leading countries of the temperate zone, Turkey has a lot of floristic diversity and endemism. Therapeutic uses of plants are based on ancient times. It has been found mainly by trial and error in Anatolia as well as all over the world and medi- 
cally important plants have been widely used in traditional folk medicine for many centuries. It is known that some widespread endemic species have different antimicrobial effects (Yiğit, Kandemir, \& Yiğit, 2002; Buruk, Sokmen, Aydin, \& Erturk, 2006; Dulger, 2006; Benli, Güney, Bingöl, Geven, \& Yiğit, 2007; Benli, Yiğit, Geven, Güney, \& Bingöl, 2009; Türker, Birinci Yıldırım, Pehlivan Karakaş, \& Köylüoğlu, 2009). While recent studies on antimicrobial activity are mostly concentrated on widespread endemic species, in this study, the antimicrobial effects of the gypsophyte species developing in gypseous soils, which are extremely arid habitats, were examined (Wagenitz, \& Kandemir, 2008; Yıldırımlı, 2012).

T. ekimii is a member of the Lamicaceae family and it is known that this family species is used in food and cosmetics as well as in the pharmaceutical industry (Bekut et al., 2018). It is known that Thymus L. (thyme) is used as a spice in meals and facilitates digestion. It is used by local people for cramps, disinfection, and as an expectorant. In studies, it has been determined that there are biological activities such as antioxidant, antiseptic, and antimicrobial (Benli \& Yiğit, 2005).

Some species of the genus Verbascum L., including V gypsicola, have been used extensively for centuries to treat internal and external infections. It is traditionally used by local people as a tea, and is believed to have a chest loosening and expectorant effect. In addition, some species of the Verbascum L. genus have biological effects such as antimalarial, antiviral, antitumor, antihepatotoxic, antihyperlipidemic, antioxidant, anti-inflammatory, antinociceptive, wound-healing, antimicrobial, anthelmintic, sedative, pre-anesthetic, and anxiolytic (Civelek, 2018).

The genus Glaucium Mill., which includes the species G. secmenii, has been used by local people for food and medical purposes. Some species'seeds, green parts, and petals are used. It is stated in some studies that it is effective in colds, bronchitis, and in conditions such as expectorant and for insomnia (Saraç et al., 2018).

There are not many studies on the antimicrobial activities of taxa belonging to the genus Psephellus Cass., which also includes the $P$. erzincani species, and some species have been examined for their cytotoxic, antioxidant and anti-inflammatory activities (Korkmaz et al., 2019; Demiroz, Nalbantsoy, Aydin, \& Baykan, 2020).
The genus Psephellus has been separated from Centaurea, and some Centaurea species are used for fever, diabetes, hemorrhoids, and peptic ulcers for therapeutic purposes among people. In pharmacological and phytochemical studies, antioxidant, antimicrobial, and antipyretic properties have been determined in many different Centaurea species (Korkmaz et al., 2019).

In this study, it was aimed to determine the antimicrobial activities of the extracts obtained from a methanol solvent of local gypsophyte endemics T. ekimii, V. gypsicola, G. secmenii and P. erzincani.

\section{MATERIALS AND METHODS}

\section{Collection and identification of plant material}

The common feature of plants is that they are local endemic species spread on gypsum soils, which are extremely excavated arid habits for plant life. Plant materials were diagnosed using Flora of Turkey and East Aegean Islands (Ekim 2000). Identified plant samples were checked in the ANK Herbarium, and the doublet of the plants was preserved in the ANK Herbarium (Table 1).

\section{Extract of plant material}

T. ekimii, G. secmenii, V. gypsicola, P. erzincani were dried and after milling added to the $40 \mathrm{~mL}$ 98\% methanol by weighing 1 g for each sample.

Each sample was kept on a rotary shaker at 100 rpm for 72 hours to obtain the extract. It was then filtered using Whatman filter paper and stored at $4^{\circ} \mathrm{C}$ for further study. Then $20 \mu \mathrm{L}$ (500 $\mu \mathrm{g} / \mathrm{L}$ ) extracts were injected into $6 \mathrm{~mm}$ diameter empty antibiotic discs (Erecevit Sönmez, Kırbağ, \& Inci, 2019).

\section{Test microorganisms}

In this study; Escherichia coli ATCC 25322 and Bacillus megaterium DSM32 as bacteria, and Candida albicans FMC17 as fungi were used. Microorganism cultures were obtained from the Firat University, Faculty of Science, Department of Biology, Microbiology Laboratory culture collection.

\section{Preparation of microorganism cultures and testing of antimicrobial effect}

The antimicrobial activity of extracts of plant samples obtained using methanol was determined according to the disk diffusion method (Collins \& Lyne, 1989).

Table 1. The location and GPS coordinates and elevation of species extracted

\begin{tabular}{|c|c|c|}
\hline Species & Locality, Collector and Number of plants & Elevation $(\mathrm{m})$ \\
\hline Thymus ekimii Yildirimli & $\begin{array}{l}\text { Between Așağıkepen and Kepen villages / Eskișehir } \\
39^{\circ} 22^{\prime} 10.0^{\prime \prime} \mathrm{N} 031^{\circ} 2909.1^{\prime \prime} \text { E, 05.06.2020 } \\
\text { Kurt, L., } 15214\end{array}$ & 938 \\
\hline Glaucium secmenii Yildirimli & $\begin{array}{l}\text { Ankara-Eskișehir road side / Eskișehir } \\
39^{\circ} 33^{\prime} 51.4^{\prime \prime} \mathrm{N} 031^{\circ} 48^{\prime} 27.9^{\prime \prime} \text { E, 05.06.2020 } \\
\text { Kurt, L., } 14938\end{array}$ & 988 \\
\hline Verbascum gypsicola Vural \& Aydogdu & $\begin{array}{l}\text { Beypazarı-Nallıhan road, near Çayırhan / Ankara } \\
40^{\circ} 06^{\prime} 24.3^{\prime \prime} \mathrm{N} 031^{\circ} 43^{\prime} 45.5^{\prime \prime} \mathrm{E}, 06.06 .2020 \\
\text { Kurt, L., } 15583\end{array}$ & 611 \\
\hline $\begin{array}{l}\text { Psephellus erzincani Wagenitz \& } \\
\text { Kandemir }\end{array}$ & $\begin{array}{l}\text { Ilic-Divrigi road, near Bagistas village / Erzincan } \\
39^{\circ} 27^{\prime} 02.1^{\prime \prime} \mathrm{N} 038^{\circ} 28^{\prime} 52.4^{\prime \prime} \mathrm{E}, 12.06 .2020 \\
\text { Kurt, L., } 14701\end{array}$ & 889 \\
\hline
\end{tabular}


Bacterial strains (E. coli ATCC25322, B. megaterium DSM32), were incubated in Nutrient Buyyon (Difco) for 24 hours at $35 \pm 1^{\circ} \mathrm{C}$ and the yeast strain (C. albicans FMC 17) was incubated at $25 \pm 1^{\circ} \mathrm{C}$ for 48 hours in Malt Extract Buyyon (Difco). Cultures grown in broth medium were adjusted to the 0.5 McFarland standard. The culture of prepared bacteria and yeast in broth are as follows; Mueller Hinton Agar and Yeast Malt Extract Agar were inoculated with $1 \%\left(10^{6}\right.$ cells $/ \mathrm{mL}$ of bacteria, $10^{4}$ cells/ $\mathrm{mL}$ yeast and cells $/ \mathrm{mL}$ as per Mc Farland standard) and after shaking well, $25 \mathrm{ml}$ were placed in sterile petri dishes with a diameter of $9 \mathrm{~cm}$ and homogeneous dispersion was provided.

Six mm diameter antimicrobial discs (Oxoid), each of which was absorbed $20 \mu \mathrm{l}$ of different extracts, were placed in the solidified agar medium aseptically.

After the petri dishes prepared in this way were kept at $4^{\circ} \mathrm{C}$ for 1.5-2 hours, the bacteria grafted plates were incubated at $37 \pm 0.1^{\circ} \mathrm{C}$ for 24 hours, and the yeast-grafted plates at $25 \pm 0.1^{\circ} \mathrm{C}$ for 72 hours.

As a control, different standard discs were used for bacteria (Piperacillin/Tozabactam $110 \mu \mathrm{g} /$ disk) and yeasts (Mycostatin $30 \mu \mathrm{g} /$ disk).

Inhibition zones formed on the medium at the end of the period were evaluated in $\mathrm{mm}$.

\section{RESULTS AND DISCUSSION}

The antimicrobial effects of T. ekimii, G. secmenii, V. gypsicola, P. erzincani methanol extracts against B. megaterium DSM32, E. coli ATCC25322 and C. albicans FMC17 are shown in Table 2. Mycostatin (30 $\mathrm{\mu g} /$ disk) used for yeasts created a $15 \mathrm{~mm}$ inhibition zone against C. albicans FMC17. Piperacillin/Tozabactam $(110 \mu \mathrm{g} /$ disk) prevented the growth of tested bacteria at different rates (25-38 $\mathrm{mm}$ inhibition zone).

Table 2. Antimicrobial effects of T. ekimii, G. secmenii, V. gypsicola and $P$. erzincani.

\begin{tabular}{|c|c|c|c|}
\hline & \multicolumn{3}{|c|}{ Diameter of Inbition Zone ( $\mathrm{mm}$ ) } \\
\hline & 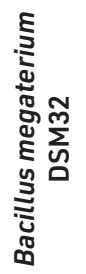 & 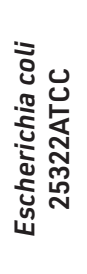 & 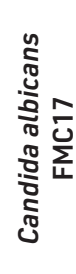 \\
\hline $\begin{array}{l}\text { Thymus } \\
\text { ekimii }\end{array}$ & 11 & 10 & 14 \\
\hline $\begin{array}{l}\text { Glaucium } \\
\text { secmenii }\end{array}$ & 11 & 10 & 12 \\
\hline $\begin{array}{l}\text { Verbascum } \\
\text { gypsicola }\end{array}$ & 8 & 7 & 7 \\
\hline $\begin{array}{l}\text { Psephellus } \\
\text { erzincani }\end{array}$ & 23 & 15 & 23 \\
\hline Control & 25 & 38 & 15 \\
\hline
\end{tabular}

Against B. megaterium DSM32 T. ekimii, G. secmenii and V. gypsicola formed a $11 \mathrm{~mm}$ and $8 \mathrm{~mm}$ zone diameter respectively, while the inhibition zone of $P$. erzincani was measured at $23 \mathrm{~mm}$ (Figure 1). It has been determined that T. ekimii, G. secmenii, V. gypsicola, P. erzincani prevent the development of E. coli ATCC25322 at different rates (7-15 mm) (Figure 2). T. ekimii, G. secmenii, V. gypsicola and P. erzincani species formed $14 \mathrm{~mm}, 12 \mathrm{~mm}, 7 \mathrm{~mm}$ and $23 \mathrm{~mm}$ inhibition zones against C. albicans FMC17, respectively (Figure 3). According to the results obtained, the P. erzincani extract showed the best antimicrobial activity against B. megaterium DSM32 (23 mm), E. coli ATCC25322 (15 mm) and C. albicans FMC17 (23 mm).

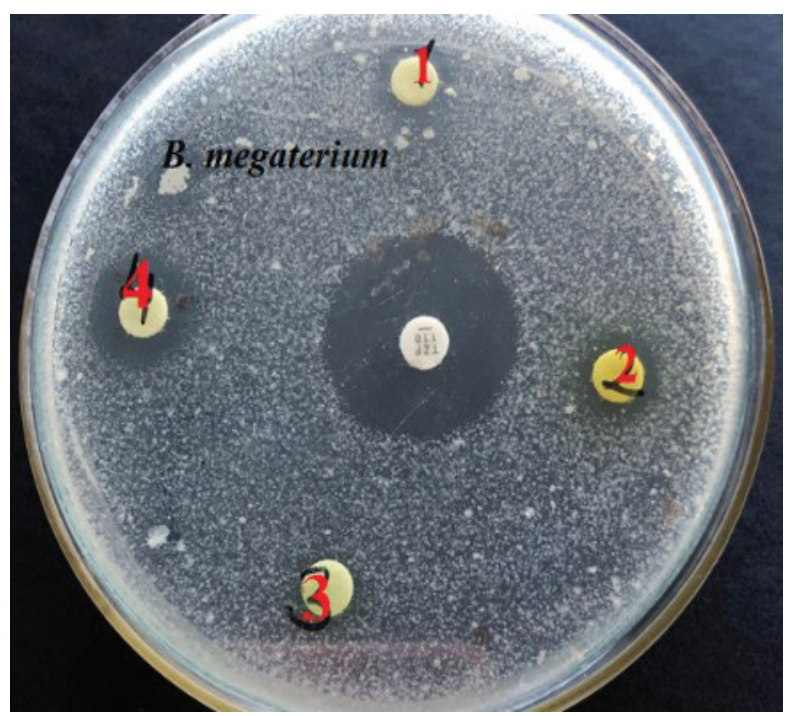

Figure 1. Antimicrobial effects of narrow endemic gypsopyhte against B. megaterium (numbers in petri; 1- T. ekimii; 2- G. secmenii; 3- V. gypsicola; 4- P. erzincani).

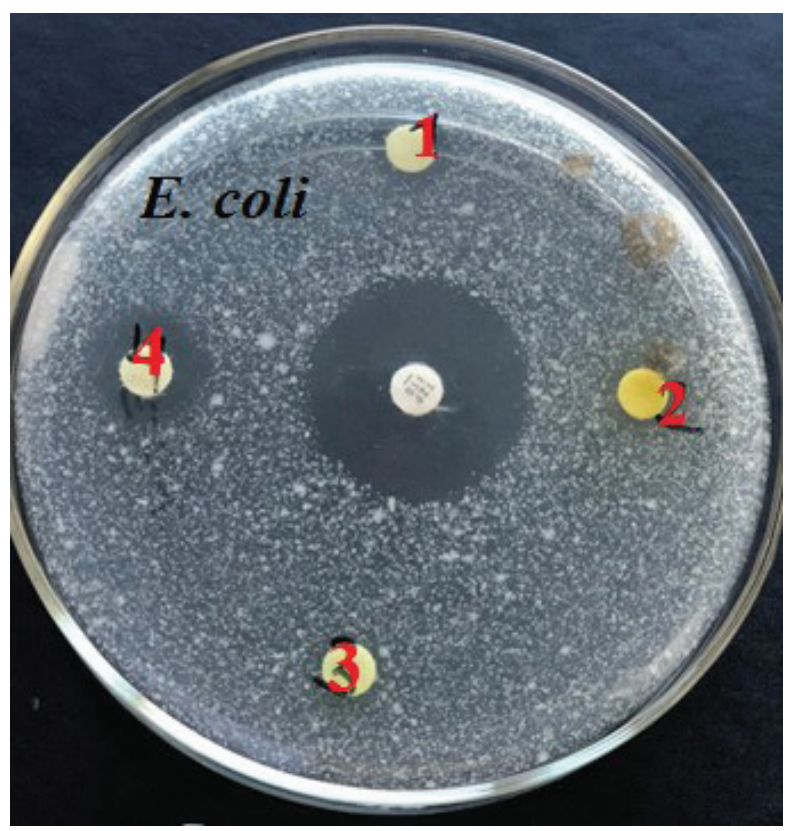

Figure 2. Antimicrobial effects of narrow endemic gypsopyhte $E$. coli (numbers in petri; 1- T. ekimii; 2- G. secmenii; 3- V. gypsicola; 4- P. erzincani). 


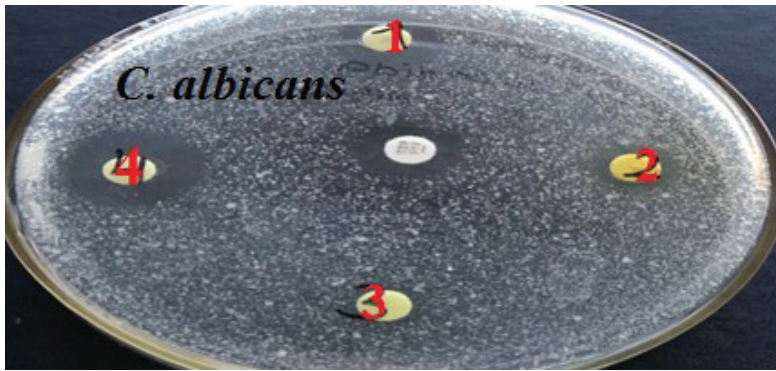

Figure 3. Antimicrobial effects of narrow endemic gypsopyhte against C. albicans (numbers in petri; 1- T. ekimii; 2- G. secmenii; 3-V. gypsicola; 4- P. erzincani).

The antimicrobial activity of some Thymus species have been shown in other previous studies. In the studies conducted, it was determined that essential oils obtained from Thymus algeriensis prevent the development of S. aureus ATCC25923, B. subtilis 166, S. enteridis ATCC502, E. coli GM109, P. aeruginosa and L. monocytogynes at different rates (9-74 mm inhibition zone) (Guesmi, Mouna, Mondher, \& Ahmed, 2014). In a different study, the antimicrobial effect of essential oils of T. vulgaris $L$. against different strains of E. coli 25922 was determined as 22.7$2.8 \mathrm{\mu} \mathrm{ml}^{-1}$, and antimicrobial effect against different strains of S. aureus ATCC25923, ATCC6538 as 11.4-45.4 $\mu \mathrm{m} \mathrm{ml}^{-1}$. It has been reported that essential oils of the same species show $0.11 \mu \mathrm{l}$ $\mathrm{ml}^{-1}$ antimicrobial activity against different strains of $C$. albicans ATTC10231 (Bogavac et al., 2015). The essential oils of Thymus longicaulis subsp. longicaulis were found to have an antimicrobial effect of $0.781 \mu \mathrm{g} / \mathrm{ml}$ against S. aureus ATCC25923 and $0.098 \mu \mathrm{g} / \mathrm{ml}$ against E. coli and C. albicans DSMZ1386 (Demiryapan, 2020). It was determined that Thymus serphllum ethanol, methanol, and water extracts did not prevent the development of E. coli ATCC11229 at a concentration of $150 \mathrm{mg} / \mathrm{ml}$, and the ethanol and methanol extract prevent the development of C. albicans RSKK02029 (8 mm inhibition zone) (Ökmen, Arslan, Vurkun, Mammadkhanli, \& Ceylan, 2017). The essential oils of Thymus vulgaris have been reported to have $49.27 \pm 7.26$ $\mathrm{mm}$ against S. aureus NCTC8530 and $39.55 \pm 0.52 \mathrm{~mm}$ against $E$. coli BL21 (Kılıç, 2019).

The antimicrobial effects of methanol, ethanol, and water extracts of Verbascum degenii against some hospital pathogens were investigated. In the results obtained, while methanol extract formed an inhibition zone of $20 \pm 1.6 \mathrm{~mm}$ against $S$. aureus, ethanol extract formed an inhibition zone of $21 \pm 1.5 \mathrm{~mm}$, and no inhibition zone was observed in water extract (Avşar, Keskin, \& Berber, 2016).

While the water extract of Glaucium grandiflorum Boiss. \& Huet var. grandiflorum has antimicrobial effects $>5 \mathrm{mg} / \mathrm{ml}$ against E. coli ATCC25922, 0.625 mg/ml against S. aureus ATCC29213 and $>5 \mathrm{mg} / \mathrm{ml}$ against C. albicans ATCC10231; ethanol extract against the same microorganisms showed antimicrobial effects $>5 \mathrm{mg} / \mathrm{ml}, 5 \mathrm{mg} / \mathrm{ml}$ and $1.25 \mathrm{mg} / \mathrm{ml}$, respectively (Saraç et al., 2018).

Many microorganisms that harm human health show resistance to drugs due to using unnecessary and wrong antibiotics. Therefore, there is a need to discover new substances from natural sources, including plants. In this study, the antimicrobial activity of gypsophytes grown in gypsiferous soils, which are extreme habitats for plants, were investigated. The species discussed in this study are local endemic gypsophytes and their antimicrobial activities were examined for the first time. It has been predicted that species growing in extreme habitats may have high antimicrobial activities.

Among the four gypsophytes examined in this study, P. erzincani extract showed the best antimicrobial activity against $B$. megaterium DSM32 (23 mm), E. coli ATCC25322 (15 mm) and C. albicans FMC17 (23 mm). Investigating the antimicrobial activities of species grown in extreme habitats may lead to new antibiotic research.

The results obtained show that antimicrobial effects of T. ekimii, $V$. gypsicola, G. secmenii and P. erzincani are different from Thymus algeriensis, T. vulgaris, T. longicaulis subsp. longicaulis, T. serpyllum, Glaucium grandiflorum var. grandiflorum in literature. As a result of the adaptation of these plants (T. ekimii, V. gypsicola, G. secmenii and P. erzincani) to extreme habitats (gypsum soils etc.), their defense systems are well developed and have a high resistance against drought, bacteria, viruses, and other pathogens. Therefore, it is very important that research of the antimicrobial effects of plant pecies living in these extreme conditions and their use as an antimicrobial agent against microorganisms receive further investigation and study.

In conclusion, these four narrow endemic plants, especially $P$. erzincani, have the potential for use as antimicrobial agents. Endemic plant species as antimicrobial agents are substantial in pharmacology and more investigation is necessary in terms of contributing to the literature.

Peer-review: Externally peer-reviewed.

Author contributions: Conception/Design of Study- E.O., S.K., L.K.; Data Acquisition-L.K., E.Ö.; Data Analysis/Interpretation-Ş.I., S.K., A.H.E.; Drafting Manuscript- E.O., L.K., E.Ö., S..l.; Critical Revision of Manuscript-E.O.; Final Approval and Accountability- E.O., S..I, D.Ö., S.A.Ş., E.Ö., S.K., A.H.E., L.K.

Conflict of Interest: The authors have no conflict of interest to declare.

Financial Disclosure: Authors declared no financial support.

\section{REFERENCES}

- $\quad$ Avşar, C., Keskin, H., \& Berber, I. (2016). Hastane infeksiyonlarından izole edilen mikroorganizmalara karşı bazı bitki ekstraktlarının antimikrobiyal aktivitesi. [Antimicrobial Activityof Some Plant Extracts against Microorganisms Isolated from Hospital Infections]. International Journal of Pure and Applied Sciences, 2(1), 22-29.

- Bekut, M., Brkic, S., Kladar, N., Dragovic, G., Gavaric, N., \& Božin, B. (2018). Potential of selected Lamiaceae plants in anti(retro)viral therapy. Pharmacological Research, 133, 301-314. https://doi. org/10.1016/j.phrs.2017.12.016

- Benli, M., \& Yiğit, N. (2005). Ülkemizde yaygın kullanımı olan kekik (Thymus vulgaris) Bitkisinin Antimikrobiyal Etkisi. Orlab On-Line Mikrobiyoloji Dergisi, 3(8), 1-8.

Benli, M., Güney, K., Bingöl, Ü., Geven, F., \& Yiğit, N. (2007). Antimicrobial activity of some endemic plant species from Turkey. African Journal of Biotechnology, 6(15), 1774-1778. 
- Benli, M., Yiğit, N., Geven, F., Güney, K., \& Bingöl, Ü. (2009). Antimicrobial activity of endemic Digitalis lamarckii Ivan from Turkey. Indian Journal of Experimental Biology, 47(3), 218-21.

- Bogavac, M., Karaman, M., Janjusevic, L., Sudji, J., Radovanovic, B., Novakovic, Z. ... Bozin, B. (2015). Alternative treatment of vaginal infections - in vitro antimicrobial and toxic effects of Coriandrum sativum L. and Thymus vulgaris L. essential oils. Journal of Applied Microbiology, 119, 697-710. https://doi:10.1111/jam.12883

- Blonk, B., \& Cock, IE. (2019). Interactive antimicrobial and toxicity profiles of Pittosporum angustifolium Lodd. extracts with conventional antimicrobials. Journal of Integrative Medicine, 17, 261-272. https://doi.org/10.1016/j.joim.2019.03.006

- Buruk, K., Sokmen, A., Aydin, F., \& Erturk, M. (2006). Antimicrobial activity of some endemic plants growingin the Eastern Black Sea Region, Turkey. Fitoterapia, 77, 388-391. https://doi:10.1016/j.fitote.2006.03.002

- Civelek, ED. (2018). Verbascum pyramidatum Bieb. Üzerinde Farmakognozik Araştırmalar in Hacettepe University, (Master's Thesis). Retrieved from http://www.openaccess.hacettepe.edu.tr

- Collins, C.H., Lyne, P.M., Grange, J.M. \& Flkinham III, J.O. (2004). Microbiological Methods, (p. 140), London, Arnold.

- Demiroz, T., Nalbantsoy, A., Aydin, K., \& Baykan, S. (2020). Phytochemical composition and antioxidant, cytotoxic and antiinflammatory properties of Psephellus goeksunensis (Aytaç \& $\mathrm{H}$. Duman) Greuter \& Raab-Straube. South African Journal of Botany, 130, 1-7. https://doi.org/10.1016/j.sajb.2019.11.021

- Demiryapan, A. (2020). Teucrium polium L. ve Thymus longicaulis subsp. Iongicaulis C. Presl Bitkilerinden Elde Edilen Uçucu Yağların GC-MS Analizi Ve Antimikrobiyal Aktiviteleri in Kastamonu University, (Master's Thesis). Retrieved from http:// https://tez.yok.gov. tr/UlusalTezMerkezi/tezSorguSonucYeni.jsp

- Dulger, B. (2006). Antimicrobial Activity of Some Endemic Scrophulariaceae from Turkey. Pharmaceutical Biology, 44(9), 672-676. https://doi.org/10.1080/13880200601009099

- Ekim, T. (2000). Verbascum In Güner, A., Özhatay, N., Ekim, T., \& Başer, K.H.C. (eds.). Flora of Turkey and the East Aegean Islands, Vol. XI (Supplement 2). (p. 193). Edinburgh, UK: Edinburgh University Press

- $\quad$ Erecevit Sönmez P., Kırbağ S., \& Inci Ş. (2019). Antifungal and Antibacterial Effect of Dodder (Cuscuta campestris) Used for Hepatitis Treatment of Mothers and Newborn Infants in Province Mardin in Turkey. Yüzüncü Yıl Üniversitesi Tarım Bilimleri Dergisi, 29(4), 722730. https://doi.org/10.29133/yyutbd.605970

- $\quad$ Guesmi, F., Mouna, B.F., Mondher, M., \& Ahmed, L. (2014). In-vitro assessment of antioxidant and antimicrobial activities of methanol extracts and essential oil of Thymus hirtus sp. algeriensis. Lipids in Health and Disease, 13, 114. https://doi:10.1186/1476-511X-13-114

- Hutchings, A., \& Cock, I.E. (2018). An interactive antimicrobial activity of Embelica officinalis Gaertn. fruit extracts and conventional antibiotics against some bacterial triggers of autoimmune inflammatory diseases. Pharmacognosy Journal, 10(4), 654-62. https://doi:10.5530/pj.2018.4.108
Kılıç, Ö. (2019). Bazı Bitkilerde Uçucu Yağların Biyoaktifve Antimikrobiyal Özelliklerinin Araştırılması in Ordu University, (Master's Thesis). Retrieved from http://earsiv.odu.edu.tr

Korkmaz, N., Ozlem Sener, S.O., Balturk, N., Kanbolat, S., Badem, M., Aliyazicioglu, R. ... Alpay Karaoglu, S. (2019). Determination of Phenolic Contents by HPLC, and Antioxidant, Antimicrobial, Antityrosinase, and Anticholinesterase Activities of Psephellus hubermorathii. Journal of Pharmaceutical Research International, 26(1), 1-10. https://doi:10.9734/JPRI/2019/v26i130125

- $\quad$ Mummed, B., Abraha, A., Feyera, T., Nigusse, A., \& Assefa, S. (2018). In Vitro Antibacterial Activity of Selected Medicinal Plants in the Traditional Treatment of Skin and Wound Infections in Eastern Ethiopia, BioMed Research International, Volume 2018, 8, Article 1862401. https://doi.org/10.1155/2018/1862401

- Ö̈kmen, G., Arslan, A., Vurkun, M., Mammadkhanli, M., \& Ceylan, O. (2017). Farklı Baharatların Antimikrobiyal ve Antioksidan Aktiviteleri. Elektronik Mikrobiyoloji Dergisi, 15(1): 16-28.

- $\quad$ Özdek, U., Seçkin, H., \& Çibuk, S. (2020). Investigation of Antimicrobial Effects of Amygdalus trichamygdalus (Sweet Almond) and Amygdalus nana L. (Bitter Almond) Plants. Van Veterinary Journal, 31(1), 22-26. https://doi.org/10.36483/vanvetj.651515

- Saraç, H., Daştan, T., Durukan, H., Durna Daştan, S., Demirbaş, A., \& Karaköy, T. (2018). Kırmızı Gelincik (Fam: Papaveraceae, Glaucium grandiflorum Boiss.\& Huet var. grandiflorum) Bitkisinin Farklı Özütlerinin Besin Elementi l̇çeriğinin ve In Vitro Antiproliferatif Etkilerinin Değerlendirilmesi. Süleyman Demirel Üniversitesi Ziraat Fakültesi Dergisi, 1. Uluslararası Tarımsal Yapılar ve Sulama Kongresi Özel SayıII, 417-428.

- Türker, H., Birinci Yıldırım, A., Pehlivan Karakaş, F., \& Köylüoğlu, H. (2009). Antibacterial Activities of Extracts from Some Turkish Endemic Plants on Common Fish Pathogens. Turkish Journal of Biology, 33, 73-78. https://doi:10.3906/biy-0805-18

- Van Vuuren, S., \& Viljoen, A. (2011). Plant-based antimicrobial studies - methods and approaches to study the interaction between natural products. Planta Medica, 77(11),1168-82. http:// dx.doi.org/10.1055/s-0030-1250736

- Wagenitz, G., \& Kandemir, A. (2008). Two new species of the genus Psephellus (Compositae, Cardueae) from eastern Turkey. Willdenowia, 38, 521-526.

- $\quad$ Yıldırımlı, s. (2012). The heaven of gypsophilous phytodiversity of Turkey: Kepen, Sivrihisar, Eskişehir, Turkey, 13 taxa as new. The Herb Journal of Systematıc Botany, 19(2), 1-51.

- Yiğit, D., Kandemir, A., \& Yiğit, N. (2002). Antimicrobial Activity of Some Endemic Plants (Salvia cryptantha, Origanum acutidens, Thymus sipyleus ssp. sipyleus). Erzincan Eğitim Fakültesi Dergisi, 4(2), 77-81. 